\title{
Determination of Long and Short Run Demand for Money in the West African Monetary Zone (WAMZ) Countries: A Panel Analysis
}

\author{
Agya Atabani Adi * and Joshua Sunday Riti \\ *Federal University Wukari \\ -University of Jos
}

Submitted: May 29, 2017 • Accepted: August 11, 2017

\begin{abstract}
This paper examines demand for real money balances in six West African countries from 1985-2014 using a panel cointegration technique. Real income and inflation rate positively affect demand for money, whereas interest rate spread, real effective exchange rate, and the U.S. real interest rate negatively affect broad money demand in the long run. Income elasticity is greater than unity in the long term and less than unity in the short term. All the variables examined are significant except effective exchange rate. Both the currency substitution and capital mobility hypotheses hold for the long run, but only the capital mobility hypothesis holds in the short run. We recommend that monetary aggregate grow more slowly than economic growth to maintain price stability. Countries should maintain a stable exchange rate and ensure a market driven interest rate policy.
\end{abstract}

JEL classification: E41, E52, C33, O11

Keywords: demand for money, interest rate spread, capital mobility, currency substitution, panel analysis

${ }^{*}$ Corresponding Author. Address: Department of Economics, Faculty of Humanities, Social and Management Sciences, Federal University Wukari, Taraba State, PMB 1020, Nigeria. Email: atabaniadi@yahoo.com

${ }^{\dagger}$ Address: Department of Economics, Faculty of Social Sciences, University of Jos, Plateau State, 930001, Nigeria 


\section{Introduction}

Monetary integration and adoption of indirect monetary policy instruments in economic management have brought a new paradigm shift in the formulation and implementation of monetary policy in West African countries, especially among West African Monetary Zone (WAMZ) member countries. On the one hand, regional economic corporations require monetary authorities to shift their focus from national to regional macroeconomics management. The adoption of indirect policy instruments, on the other hand, introduces market forces to regional financial markets and makes the effects of monetary policy more difficult to predict. The formulation of effective and efficient money demand functions cannot be overemphasized in the design and implementation of monetary policy in developed and developing economies alike. Disequilibrium in demand for money might undermine the effectiveness of interest rate transmission mechanisms in the long run through its effect on inflation and output in developing countries.

Concerted efforts have been devoted to this issue in the recent past due to its importance in modern macroeconomics. Despite the huge interest, research related to issues in demand for money in sub-Saharan Africa have been limited (Jenkins, 1999; Rother, 1999; Nachega, 2001; Pedroni, 2004). Understanding demand for money is a necessary, important, and significant prerequisite for the formulation of stabilization and economic adjustment programs in developing countries, where limits are set on the expansion of domestic credit to be consistent with growth in demand for money.

Policy makers and economists analyse and estimate money demand functions for at least two reasons. First, the income elasticity of money demand tells us the rate of monetary expansion that is consistent in the long run. Second, the interest elasticity of money demand allows policy makers to determine the long term welfare cost of inflation on the economy. Demand for money is considered an important instrument of stabilization policies where such policy depends on the capacity to adjust money supply to equal demand, in order to prevent monetary distortion from affecting real variables. It is believed that the relationship between money supply and income, prices, and balance of payments is determined by demand for money. This relationship plays an important role in macroeconomic issues such as economic growth, price stability, unemployment, and the balance of payments in any nation.

The efficacy of monetary policy regimes depends on the strength of monetary transmission mechanisms and the velocity of money in an economy. When these relationships are subject to unintended shifts, monetary targets lose their transparency and are less able to accurately provide signals for the appropriate stance of monetary policy. This has been the reason for the switch to inflation targeting, which does not rely on the stability of demand for money and instead uses a broad range of information to assess monetary policy stance (Mishkin, 1999). 
Although many studies have been done on money demand functions in individual countries, sub-regions, and Africa as a whole, there have not been any studies done on sub-regional WAMZ countries. None of the studies used interest rate spreads other than single interest rates, which do not really capture the opportunity costs of holding real money balances. Furthermore, none of them examined currency substitution and capital mobility for the WAMZ member countries. Hence the need for this paper to shed light on this important policy tool - interest rate spread, now that these countries are moving towards homogenous monetary policy when the currency union in WAMZ countries comes alive.

This paper employs interest rate spread to examine the effect of interest rate on demand for money in the WAMZ countries, albeit with the single interest rate used in previous studies and recognizing that with financial sector deregulation and innovation, the single interest rate does not adequately capture the opportunity costs of money. We investigated empirically whether the so-called currency substitution and capital mobility hypotheses hold in this region, and determined which variable has the greater effect on real money demand. The objective was to empirically determine the plausibility of the null hypothesis that income elasticity equals unity in the short run, and whether foreign real interest rate, inflation rate, and effective real exchange rate negatively affect real money demand.

The subsequent part of this paper is structured as follows: Section 1 provides a brief review of relevant empirical research in the literature. Section 2 details the econometric methodology employed and Section 3 presents an econometric analysis of the results obtained. The last section offers some concluding remarks on our research.

\section{Literature review}

The subject of money demand in developing and developed countries is well documented for many different time periods. Most literature on sub-Saharan Africa indicates that money demand is stable: this view is supported by Suliman and Dafaalla (2011); Bahmani-Oskooee (2009); Hamori et al. (2008); Salisu et al. (2013). Bitrus (2011) used annual time series spanning 26 years to examine narrow and broad money, income, interest rate, exchange rate, and the stock market. He found a stable demand for money function in Nigeria, with income as the most significant determinant of demand for money. He also found that stock market instruments improved the demand for money function. Kovanen et al. (2011) adopted bounds testing procedures to test the stability of long run money demand in Ghana. They found a strong, stable long run demand for money function in spite of substantial changes in the financial markets, and deviations from equilibrium were short lived. Kumar et al. (2013) investigated the stability of money demand in Nigeria from 1960 to 2008. They employed canonical and alternative specifications by proxy for the cost of holding money. They found 
that the Nigerian regime shift in 1986 improved demand for money marginally, and that demand for money was stable overall. They concluded that broad money stock can be used effectively as an instrument of monetary policy. Bahmani (2008) found stable demand for money in the majority of Middle East countries. Rother (1999) analyzed demand for money across the entire West African Economic and Monetary Union (WAEMU), the six smaller member countries and Côte d'Ivoire, finding a stable aggregate money demand function in the sub-region. In contrast to the findings above, some studies indicate the instability of money demand in transition and developing countries. For example, Kararach (2002) found no evidence of a stable money demand in Uganda, and Dekle and Pradhan (1997) found money demand to be unstable in Asian countries. Tahir (1995) attributed instability of money demand functions to financial innovation leading to fundamental change in-and possibly the instability of-money demand. Similarly, Arrau et al. (1995) stated that taking financial innovation into account in money demand functions could help solve auto-correlation errors, persistent over-prediction, and incredible parameter estimate problems in money demand functions. Nell (1999) examined stable long run demand for money in South Africa using annual data spanning the period of 1965-1997. He found a stable long run money demand function for M3 in South Africa, while the M1 and M2 money demand functions showed unstable parameters after financial reforms in 1980. Nell (1999)'s results support the use of M3 money stock as the nominal anchor for the South African Reserve Bank's monetary policy.

Ogunsakin and Awe (2014) employed multivariate cointegration methods to estimate the relationship between $\mathrm{M} 1, \mathrm{M} 2$, and domestic inflation, gross domestic product, foreign interest rate, exchange rate, savings deposit and Treasury bill rates. There were two cointegrating vectors: income elasticity was positive and significant in the long run, and inflation, foreign interest, and domestic interest rates were statistically significant and correctly signed. The speed of adjustment was 34 percent and 56 percent for M2 and M1, respectively. They concluded that financial liberalization has not altered money demand stability and monetary aggregate remains a valuable policy instrument in Nigeria.

Tano (2011) investigated stability of money and money demand for Côte d'Ivoire, finding a long run equilibrium relationship between M1 (or M2) and its determinants - real income and expected inflation. The income elasticity with respect to M2 was 1.40 while income elasticity with respect to M1 was 0.94 (i.e. less than unity). Herve and Shen (2011) examined money supply (M2) and its main determinants (real income and interest rate) in Côte d'Ivoire from 1980 to 2007 using the Juselius and Johansen cointegration test. They found that long run relationships exist and the independent variables significantly affected the dependent variable with a correct sign. Niyimbanira (2013) examined whether there is a stable long run equilibrium relationship between real demand for money and independent variables in South 
Africa. The cointegration test confirmed the existence of stable equilibrium relationships and the error correction model (ECM) showed that monetary policy is effective in South Africa.

Hamori et al. (2008) empirically examined demand for money functions in the sub-Saharan African region, using non-stationary variables in a panel data analysis for 35 countries spanning from 1980 to 2005. He found cointegration relationships exist for money demand functions in the sub-Saharan African region. Valadkhani and Alauddin (2003) examined determinants of demand for real money balances in eight developing countries by pooling cross-country and time series data from 1979 to 1999. They found an increase in real income had significant positive effects, whereas an increase in interest and inflation rates negatively affected real demand for money.

\section{Methodology}

Following Arize et al. (1999), Agénor and Khan (1996), and Bahmani-Oskooee and Rhee (1994), this paper complements the traditional demand for money function with interest rate spread (the difference between the time deposit and lending rates), real effective exchange rate (REER), and the U.S. real interest rate $\left(R_{U S}\right)$. The demand for real money balances as a function of real income, inflation rate, REER, interest rate spread, and the RUS $R_{U S}$ as follows:

$$
M 2 / P=f\left(Y, R D-L R, P, R E E R, R_{U S}\right)
$$

Equation (1) is stated in econometric form as

$$
\begin{aligned}
\ln \left(M 2_{i} / P_{i}\right)_{t} & =\delta_{0 i}+\delta_{1} \ln \left(Y_{i}\right)_{t}+\delta_{2}\left(R D_{i}-L R_{i}\right)_{t}+ \\
& +\delta_{3} \Delta \ln \left(P_{i}\right)_{t}+\delta_{4} \ln \left(R E E R_{i}\right)_{t}+\delta_{5} R_{U S, t}+\varepsilon_{i t}
\end{aligned}
$$

where $i$ denotes a specific country and varies from 1 to $6 ; t$ is time, with the time series spanning from 1980 to 2014; $M 2$ is the stock of broad money; $P$ is the GDP deflator; $Y$ is the real GDP as a proxy for transactions and precautionary demand for money; $R D$ is the time deposit interest rate (i.e. the interest rate on time deposits); $R L$ is the lending interest rate (i.e. a proxy measuring the rate of return on assets other than money); $R_{U S}$ is the U.S. real interest rate; and $R E E R$ is the real effective exchange rate. The $R_{U S}$ is used to test the capital mobility hypothesis and $R E E R$ is used for testing the currency substitution hypothesis.

The expected sign and elasticity of the income $(Y)$ coefficient is as follows: if $\delta_{1}=1$, the quantity theory applies; if $\delta_{1}=0.5$, the Baumol-Tobin inventory theoretic approach is applicable; and if $\delta$ is greater than 1, money can be considered a luxury or some neglected 
wealth effects are present. An income elasticity of less than unity has several implications for monetary policy. For example, it may be concluded that the Friedman rule is not optimal and money supply must grow more slowly than output to achieve price stability objectives (Ball, 2000, pp.36). For a comprehensive discussion of the controversy around quantity theory see Hoffman and Rasche (2001), Laidler (1993), and Laidler (1991). We also expected negative coefficient signs for all other variables in the model (i.e. $\delta_{2}, \delta_{3}, \delta_{4}$, and $\delta_{5}<0$ ). The inflation rate, $\Delta \ln \left(P_{t}\right)=\ln \left(P_{t}\right)-\ln \left(P_{t-1}\right)$, is a proxy for measuring the return on holdings of goods and its coefficient should be negative (i.e. $\delta_{3}<0$ ). Goods such as real estate and shares are substitutes for holding domestic currency.

The real effective exchange rate, $\ln (R E E R)$, and the U.S. real interest rate, $R_{U S}$, are expected to be negatively signed (i.e. $\delta_{4}$ and $\delta_{5}<0$ ). This means that the currency substitution and capital mobility hypotheses hold. Furthermore, this also means that the depreciation of domestic currency and the rise in the U.S. real interest rate will lead to a higher propensity to invest in foreign currency, as a result of international capital mobility due to capital account liberalization in the globalization era.

We began our estimation by assuming homogeneity of all model parameters across countries and then estimated a fixed effect to capture cross-country heterogeneities by varying the intercept 0 across all countries. By estimating different intercept terms (i.e. 01, 02, $03, \ldots$ 06), the within mean is subtracted from each variable and the transformed data is estimated using the OLS method. After identifying the heterogeneities across countries, we estimated income specific elasticities across countries. Based on our desired objective and the importance of income elasticity in the demand for money equation, both the intercept (0) and income elasticity (1) were allowed to vary across countries in the long run model.

Equation (2) is restated as follows to allow both the interecept and income elasticity to vary across countries:

$$
\begin{aligned}
\ln \left(M 2_{i} / P_{i}\right)_{t} & =\delta_{0 i}+\delta_{1 i} \ln \left(Y_{i}\right)_{t}+\delta_{2}\left(R D_{i}-L R_{i}\right)_{t}+ \\
& +\delta_{3} \Delta \ln \left(P_{i}\right)_{t}+\delta_{4} \ln \left(R E E R_{i}\right)_{t}+\delta_{5} R_{U S, t}+\varepsilon_{i t}
\end{aligned}
$$

Allowing $\delta_{0 i}$ and $\delta_{1 i}$ to take specific values for each country entails a loss of degrees of freedom. This involves a trade-off between the lost degrees of freedom and the gain in terms of countryspecific parameters, as well as an enhanced goodness of fit estimate. However, it is imperative to test the functional forms of equations (2) and (3) to determine the appropriate model to be employed. Therefore, (i) the common intercept term hypothesis can be stated as $H_{1,0}$ : $\delta_{0 i}=0$, and (ii) the common income elasticity hypothesis can be stated as $H_{2,0}: \delta_{1 i}=1$, where $\mathrm{i}=1,2, \ldots, 6$. If these two hypotheses are rejected, the use of equation (3) will be justified (the gains in identifying country heterogeneity outweighing the loss of degrees of freedom). This is equivalent to testing for redundant fixed effects. 
After stating the long run model, we proceeded by modelling a short run model based on Engle-Granger's two step procedure. The estimate of a panel vector error correction (VEC) model which captures short run dynamics of demand for money is stated as follows:

$$
\begin{aligned}
\Delta \ln \left(M 2_{i} / P_{i}\right)_{t} & =\phi_{0 i}+\phi_{1} \Delta \ln \left(Y_{i}\right)_{t}+\phi_{2} \Delta\left(R D_{i}-L R_{i}\right)_{t}+\phi_{3} \Delta \ln \left(P_{i}\right)_{t}+ \\
& +\phi_{4} \Delta \ln \left(R E E R_{i}\right)_{t}+\phi_{5} \Delta R_{U S, t}+\phi_{6} \Delta \ln \left(M 2_{i} / P_{i}\right)_{t-1}+\phi_{7} E C M_{i t-1}+\nu_{i t}
\end{aligned}
$$

where $\phi_{i}$ are the estimated short-term coefficients; $\phi_{7}$ is the speed of adjustment, which measures the speed of adjustment of short-term dynamic convergence to the long run equilibrium path; and we added lagged dependent variables to ensure the residuals $\nu_{t}$ are white noise.

We applied principle of parsimony to the short run model by removing insignificant variables in equation (4) based on the battery of maximum likelihood tests. The empirical results for the parsimonious model captured short run dynamics for money demand.

\subsection{Panel Cointegration Test}

We implemented panel cointegration tests by applying the seven cointegration tests proposed by Pedroni (1999). The estimated relationship is as follows:

$$
y_{i t}=\alpha_{i}+\gamma_{i t}+\theta t+\beta_{1} x_{1, i t}+\ldots+\beta_{k} x_{k, i t}+\varepsilon_{i t}
$$

where $k$ is the number of regressors and $\beta_{1}, \beta_{2}, \ldots, \beta_{k}$ are the elasticities. The deterministic elements are defined as above and $\theta t$ are common time effects.

\subsection{Unit root tests}

Pooled time series data, like univariate time series data, usually exhibit a time trend which is non-stationary. Hence, direct application of OLS or GLS to non-stationary data produces regression results that are spurious or misspecified (Engle and Granger, 1987).

This paper adopts the methodologies of Levin et al. (2002), Breitung (2000), Hadri (1999), and Im et al. (2003) for panel unit root tests that are similar to tests carried out on an individual series. However, this paper will not discuss the econometric derivation of the equation as this is beyond the scope of our research.

\section{Data and empirical results}

GDP, GDP deflator $(P)$, broad money supply $(M 2)$, the U.S. interest rate, and interest rate spread data were obtained from the World Bank. Except for Ghana and Guinea, interest 
rate spread was obtained from individual countries while real effective exchange rates were obtained from the United Nations Conference on Trade and Development (UNCTAD).

Table 1 shows the descriptive statistics for real money balance, income, interest spread, price and U.S. interest across the six countries. The real effective exchange rate has the highest mean, median, and maximum values, while price has the lowest mean, median, and maximum values. Using the standard deviation of these variables from their means as a measure of volatility shows the real effective exchange rate was the most volatile and price the least volatile of all the variables.

Table 2 presents the IPS test results and Table 3 presents the LLC test results of equations (4) and (5), showing that all variables (dependent and independent) were not stationary. This indicates that the variables were differenced once and became stationary, implying that the variables are integrated of order one.

There are seven Pedroni's tests: four are based on 'within dimension' (panel cointegration tests) and three are based on 'between dimension' (group mean panel cointegration tests). The tests' statistics are based on the null hypothesis of no cointegration for all countries i, while the alternative hypothesis is that there is cointegration for all countries i. However, the group mean panel cointegration statistics allow for heterogeneity across countries under the alternative hypothesis. Table 4 displays the results of Pedroni's tests; all panel and group mean statistics reject the null hypothesis of no cointegration at the $5 \%$ significance level. Therefore, we conclude that the variables are cointegrated, meaning there is a long run relationship among the variables.

\subsection{Functional Form Test}

The first step in panel estimation is to determine the appropriate functional form of the model. This involves determination of the homogeneity or heterogeneity of the cross section involved to decide whether pooled or fixed effect estimation is the appropriate method to use. Table 5 shows the results of the fixed effect test. With a $p$-value of 0.0000 , we reject the null hypothesis of the redundancy of fixed effects, and conclude that the fixed effects model in equation (3) is an appropriate model to use for the estimates.

Table 6 shows estimates of the parameters from equations (2) and (3) for pooled annual data from 1985 to 2014 for Guinea, Ghana, Gambia, Liberia, Sierra Leone, and Nigeria. We proceeded further by testing the two null hypotheses discussed in our methodology (i.e. $H_{1,0}: \delta_{0, i}=0$ and $\left.H_{2,0}: \delta_{1, i}=1\right)$. The tests' results are also presented in Table 6. Both hypotheses were rejected at the $5 \%$ significance level. This justified the use of country specific coefficients for intercept and income elasticity. Both Schwartz's information criterion

and Akaike's information criterion indicate equation (3) is better than equation (2). The residuals are stationary (white noise) and normally distributed, as shown in the Jarque-Bera 
normality test for equation (3) where both intercept and income elasticity are country specific.

The coefficients estimated for equations (2) and (3) are shown in Table 5. All variables have the expected signs, except the interest spread and income elasticity for Guinea in equation 3 which has the opposite sign and is not statistically significant. Other variables are highly significant in determining the real money demand functions in the WAMZ member countries, and are consistent with a priori expectations regarding the sign and the magnitude of the coefficients.

Both equations are robust in terms of goodness of fit $\left(R^{2}=0.995\right.$ and 0.993 , respectively), but only equation 3 has white noise residuals. The results presented in Table 5 are consistent with theories of demand for money. Real income and inflation rate positively affect demand for money, whereas the interest rate spread, real effective exchange rate, and U.S. real interest rate negatively affect broad money demand. However, the estimated long run country specific income elasticities in Table 4 had values higher than unity in three countries: Guinea - 3.60, Gambia - 1.95, and Sierra Leone - 2.38, the elasticities in while three other countries had values less than unity: Ghana -0.89 , Liberia -0.58 , and Nigeria -0.62 . The elasticity of income greater than unity could be attributed to political inference and shallow financial development in these three countries.

In 6 , we observe that the inflation rate (representing the opportunity cost of holding monetary assets relative to real estate assets or other assets excluding financial assets such as gold and foreign currencies) has a positive significant coefficient $\left(\delta_{3}=0.091\right)$, implying that demand for money has influenced portfolio decisions in these countries. This makes the shallow development of the stock market, or its nonexistence, in some countries in the region unsurprising.

In comparison to the interest rate spread, real effective exchange rate, and the U.S. real interest rate, the inflation rate has relatively higher effects on the real money balance in the long run. This implies that an increase in the rate of inflation discourages investors from investing in financial assets and encourages them to diversify their portfolios by acquiring real assets (Valadkhani, 2008).

The estimated coefficients for the interest rate spread $\left(\delta_{2}\right)$, the real effective exchange rate $\left(\delta_{4}\right)$, and the U.S. real interest rate $\left(\delta_{5}\right)$, are all negative (as shown in Table 6 ), indicating that the demand for real money balances is negatively affected by these three variables. All things being equal, a rise in the domestic interest rate spread or U.S. real interest rate, or currency depreciation will lead to a significant decrease in the demand for real money balances. In these circumstances, rational economic agents will diversify their portfolios in the economy by substituting foreign currencies (e.g. USD, EUR, etc.) for domestic currency in their financial portfolios or by acquiring other financial and/or real assets (e.g. real estate property, gold, and shares). 
Table 7 shows the estimated short run dynamics of real demand for money. The estimated coefficients are consistent with our expectations, with changes in inflation rate and interest rate spread reflecting the rate of return on non-financial assets and having negative coefficients of -0.125 and -0.007 , respectively. Changes in the U.S. interest rate will lead to capital outflows from domestic economies to foreign countries by $2.3 \%$ in the short run; this implies that economic agents will substitute their domestic asset holdings with foreign ones. Moreover, changes in real income exert positive effects (0.40) on money demand functions. Additionally, the ECM term is highly significant, reinforcing earlier cointegration relationships in long run money demand models. The estimated coefficients for ECM indicate an excess demand for real money balance in the last period (year) will be reduced by $39 \%$ in each subsequent year. The real effective exchange rate was removed because it was not statistically significant in the short run model.

We summarize the principal findings as follows. First, all things being equal, the long run income elasticity is greater than unity and short run income elasticity is 0.40 . We reject the null hypothesis that short run income elasticity equals unity (i.e., $\delta_{1}=1$ ), because $F(1,159)=22.20$ with $p$-value $=0.00$. The implication of this result is that - to maintain price stability in this region - the monetary aggregate growth rate must be slower than the rate of economic growth. Second, inflation has a relatively large effect on demand for money, both in the long and short run. The coefficient for inflation has the second largest magnitude, only lower than real income. Rising inflation encourages agents to diversify their portfolios away from money by acquiring real assets such as real estate property. Third, a change or rise in interest rate spread has more effect on money demand functions in the short run than it does in the long run. Fourth, both real effective exchange rate and U.S. real interest rate determine the long run demand for money. However, only the U.S. real interest rate is significant in the short run. Hence, we can conclude that the currency substitution hypothesis holds only for the long term, whereas the capital mobility hypothesis holds in both the short and long term.

\section{Conclusion and policy implications}

The formulation of effective and efficient money demand functions cannot be overemphasized in the design and implementation of monetary policy in developing economies, whether the central banker's major policy target variable is quantitative (stock of money), interest rate, or inflation.

This paper examines the long and short run determinants of demand for real money balances within the WAMZ region, pooling cross-sectional time series data spanning the years 1985 to 2014 for six countries, and implementing various fixed effects regression models 
to estimate long and short run demand for real money balances.

The Levin et al. (2002) tests for unit roots show that all variables in the models are $I(1)$. Both the Pedroni panel and Engle-Granger's two step procedures were employed to test for cointegration. The results of the tests showed that there is a long run relationship (cointegration) among the variables in the model.

We conclude that an increase in real income or inflation rate has a positive effect on demand for money, whereas the real effective exchange rate, the U.S. real interest rate, and a rise in interest rate spread all have a negative effect on demand for money in this region. This implies that real broad money supply (M2) is a predictable monetary aggregate in the region. The estimated long run income elasticity from the pooled estimation is higher than unity. Although some fixed effect models are greater than unity, others are less than unity for some countries. The implication is that, to maintain price stability in this region, the monetary aggregate growth rate must be slower than the rate of economic growth.

The dynamic error correction term, measuring the speed of adjustment of the short run dynamics of money demand to its long run path, was highly significant. The estimated coefficients for income, inflation rate, interest rate spread, and the U.S. real interest rate in this model are highly significant and consistent with a priori expectations of the direction of the signs. The estimated error correction model indicates that short run changes in income, the rate of inflation, the interest rate spread, and the U.S. real interest rate are statistically significant in determining changes in demand for money. The real effective exchange rate was statistically insignificant. One can conclude that, in this region, both the currency substitution and capital mobility hypotheses hold for the long term, whereas only the capital mobility hypothesis holds in the short term. We recommend that the monetary aggregate should grow more slowly than economic growth to maintain price stability. Countries in this region should try to maintain stable exchange rates and ensure market driven interest rate policies.

\section{References}

Agénor, P.-R. and Khan, M. S. (1996). Foreign currency deposits and the demand for money in developing countries. Journal of Development Economics, 50(1):101-118.

Arize, A. C., Malindretos, J., and Shwiff, S. S. (1999). Structural breaks, cointegration, and speed of adjustment Evidence from 12 LDCs money demand. International Review of Economics and Finance, 8(4):399 - 420.

Arrau, P., Gregorio, J. D., Reinhart, C. M., and Wickham, P. (1995). The demand for money 
in developing countries: Assessing the role of financial innovation. Journal of Development Economics, 46(2):317 - 340.

Bahmani, S. (2008). Stability of the Demand for Money in the Middle East. Emerging Markets Finance and Trade, 44(1):62-83.

Bahmani-Oskooee, M. (2009). How stable is the demand for money in African countries? Journal of Economic Studies, 36(3):216-235.

Bahmani-Oskooee, P. M. and Rhee, H.-J. (1994). Long-Run Elasticities of the Demand for Money in Korea:Evidence from Cointegration Analysis. International Economic Journal, $8(2): 83-93$.

Bitrus, Y. P. (2011). The demand for money in Nigeria. European Journal of Business and Management, 3(6):63-85.

Dekle, M. R. and Pradhan, M. (1997). Financial liberalization and money demand in ASEAN countries: implications for monetary policy. Working Paper 97/36, International Monetary Fund.

Engle, R. F. and Granger, C. W. J. (1987). Co-Integration and Error Correction: Representation, Estimation, and Testing. Econometrica, 55(2):251-276.

Hamori, S. et al. (2008). Empirical analysis of the money demand function in Sub-Saharan Africa. Economics Bulletin, 15(4):1-15.

Herve, D. B. G. and Shen, Y. (2011). The Demand for Money in Cote d'Ivoire: Evidence from the Cointegration Test. International Journal of Economics and Finance, 3(1):188.

Hoffman, D. L. and Rasche, R. H. (2001). Aggregate money demand functions: Empirical applications in cointegrated systems. Boston:Kluwer Academic Publishers.

Im, K. S., Pesaran, M., and Shin, Y. (2003). Testing for unit roots in heterogeneous panels. Journal of Econometrics, 115(1):53 - 74.

Jenkins, C. (1999). Money demand and stabilisation in Zimbabwe. Journal of African Economies, 8(3):386-421.

Kararach, G. (2002). Evidence on the demand for money function in Uganda. Technical Report WP No. 2002-01, Zimbabwe, Policy Analyst-UNICEF and others, EconWPA.

Kovanen, A., Dagher, J., et al. (2011). On the Stability of Money Demand in Ghana; A Bounds Testing Approach. Working Paper WP/11/273, International Monetary Fund. 
Kumar, S., Webber, D. J., and Fargher, S. (2013). Money demand stability: A case study of Nigeria. Journal of Policy Modeling, 35(6):978 - 991.

Laidler, D. (1991). The Quantity Theory Is Always and Everywhere Controversial-Why? The Economic Record, 67(199):289-306.

Laidler, D. (1993). The demand for money: theories, evidence and problems. Forth Edition, Harper Collins College Publishers, page 56.

Levin, A., Lin, C.-F., and James Chu, C.-S. (2002). Unit root tests in panel data: asymptotic and finite-sample properties. Journal of Econometrics, 108(1):1-24.

Mishkin, F. S. (1999). International Experiences with Different Monetary Policy Regimes. Working Paper 6965, National Bureau of Economic Research.

Nachega, J.-C. (2001). A Cointegration Analysis of Broad Money Demand in Cameroon. IMF Working Papers 01/26, International Monetary Fund.

Nell, K. S. (1999). The Stability of Money Demand in South Africa, 1965-1997. Studies in Economics Discussion Papers 9905, School of Economics, University of Kent.

Niyimbanira, F. (2013). Stability Of Money Demand In A Developing Economy: Empirical Evidence From South Africa. The International Business and Economics Research Journal, $12(5): 565$.

Ogunsakin, S. and Awe, A. (2014). Impact of financial liberalization on the stability of Nigerian money demand function. International Journal of Economics, Business and Finance, $2(1): 1-18$.

Pedroni, P. (1999). Critical Values for Cointegration Tests in Heterogeneous Panels with Multiple Regressors. Oxford Bulletin of Economics and Statistics, 61(S1):653-670.

Pedroni, P. (2004). Panel Cointegration: Asymptotic And Finite Sample Properties Of Pooled Time Series Tests With An Application To The Ppp Hypothesis. Econometric Theory, 20(03):597-625.

Rother, P. (1999). Money demand in the West African economic and monetary union - the problems of aggregation. Journal of African Economies, 8(3):422-447.

Salisu, A., Ademuyiwa, I., and Fatai, B. (2013). Modelling the Demand for Money in SubSaharan Africa (SSA). Economics Bulletin, 33(1):635-647. 
Suliman, Z. S. and Dafaalla, H. A. (2011). An econometric analysis of money demand function in Sudan, 1960 to 2010. Journal of Economics and International Finance, 3(16):793-800.

Tahir, J. (1995). Recent Developments in Demand for Money Issues: Survey of Theory and Evidence with Reference to Arab Countries. Working Papers 9530, Economic Research Forum.

Tano, G. G. (2011). Money Demand Estimation using SASß. Paper SA01-2011, Southern Illinois University Carbondale.

Valadkhani, A. (2008). Long- and Short-Run Determinants of the Demand for Money in the Asian-Pacific Countries: An Empirical Panel Investigation. Annals of Economics and Finance, 9(1):77-90.

Valadkhani, A. and Alauddin, M. (2003). Demand for M2 in Developing Countries: An Empirical Panel Investigation. School of Economics and Finance Discussion Papers and Working Papers Series 158, School of Economics and Finance, Queensland University of Technology. 
Table 1: Descriptive statistics

\begin{tabular}{lcccccc}
\hline Statistics & $M 2 / P$ & $Y$ & $R D-L R$ & $R E E R$ & $P$ & $R_{U S}$ \\
\hline Mean & 19.643 & 21.826 & 11.336 & 768.332 & 3.641 & 4.401 \\
Median & 18.575 & 21.324 & 11.000 & 35.958 & 4.214 & 4.906 \\
Maximum & 26.128 & 25.997 & 35.759 & 7014.119 & 6.265 & 7.191 \\
Minimum & 9.088 & 18.776 & -2.250 & 0.005 & -2.351 & 1.161 \\
Standard deviation & 4.148 & 1.807 & 5.989 & 1543.369 & 1.741 & 1.953 \\
Cross sections & 6 & 6 & 6 & 6 & 6 & 6 \\
\hline
\end{tabular}

Table 2: The Im, Pesaran, and Shin (2003) unit root test results

\begin{tabular}{|c|c|c|c|c|}
\hline Variables & $\begin{array}{l}\text { Intercept } \\
\text { Only }\end{array}$ & $\begin{array}{c}q \\
\text { (optimal lags length) }\end{array}$ & $\begin{array}{l}\text { Both intercept } \\
\text { and trend }\end{array}$ & $\begin{array}{c}q \\
\text { (optimal lags length) }\end{array}$ \\
\hline $\ln \left(M 2_{i} / P_{i}\right)_{t}$ & $\begin{array}{c}2.449 \\
(0.992)\end{array}$ & 2 & $\begin{array}{l}-0.386 \\
(0.349)\end{array}$ & 2 \\
\hline$\Delta \ln \left(M 2_{i} / P_{i}\right)_{t}$ & $\begin{array}{l}-5.282 \\
(0.000)\end{array}$ & 6 & $\begin{array}{l}-9.520 \\
(0.000)\end{array}$ & 0 \\
\hline $\ln \left(Y_{i}\right)_{t}$ & $\begin{array}{c}6.226 \\
(1.000)\end{array}$ & 5 & $\begin{array}{l}3.6382 \\
(0.999)\end{array}$ & 6 \\
\hline$\Delta \ln \left(Y_{i}\right)_{t}$ & $\begin{array}{l}-2.748 \\
(0.003)\end{array}$ & 4 & $\begin{array}{l}-3.495 \\
(0.000)\end{array}$ & 4 \\
\hline$\left(R D_{i}-L R_{i}\right)_{t}$ & $\begin{array}{l}-2.101 \\
(0.017)\end{array}$ & 6 & $\begin{array}{l}-1.349 \\
(0.088)\end{array}$ & 1 \\
\hline$\Delta\left(R D_{i}-L R_{i}\right)_{t}$ & $\begin{array}{l}-8.440 \\
(0.000)\end{array}$ & 5 & $\begin{array}{l}-6.330 \\
(0.000)\end{array}$ & 5 \\
\hline$\left(P_{i}\right)_{t}$ & $\begin{array}{l}12.296 \\
(1.000)\end{array}$ & 1 & $\begin{array}{c}6.479 \\
(1.000)\end{array}$ & 1 \\
\hline$\Delta \ln \left(P_{i}\right)_{t}$ & $\begin{array}{l}-3.170 \\
(0.000)\end{array}$ & 2 & $\begin{array}{l}-6.285 \\
(0.000)\end{array}$ & 3 \\
\hline $\ln \left(R E E R_{i}\right)_{t}$ & $\begin{array}{c}6.257 \\
(1.000)\end{array}$ & 3 & $\begin{array}{l}0.214 \\
(0.585)\end{array}$ & 1 \\
\hline$\Delta \ln \left(R E E R_{i}\right)_{t}$ & $\begin{array}{l}-0.747 \\
(0.000)\end{array}$ & 2 & $\begin{array}{l}-7.424 \\
(0.000)\end{array}$ & 2 \\
\hline$R_{U S, t}$ & $\begin{array}{l}-0.542 \\
(0.293)\end{array}$ & 1 & $\begin{array}{l}-1.482 \\
(0.069)\end{array}$ & 1 \\
\hline$\Delta R_{U S, t}$ & $\begin{array}{l}-2.427 \\
(0.007)\end{array}$ & 0 & $\begin{array}{l}-1.738 \\
(0.041)\end{array}$ & 0 \\
\hline
\end{tabular}

Notes: * The SIC and the Newey-West bandwidth selection method based on the Bartlett kernel are used in the test procedure. Figures in the parentheses represent the corresponding p-values.

Source: Authors' estimation. 
Table 3: The Levin et al. (2002) unit root test results

\begin{tabular}{|c|c|c|c|c|}
\hline Variables & $\begin{array}{c}\text { Intercept } \\
\text { only }\end{array}$ & $\begin{array}{c}q \\
\text { (optimal lags length) }\end{array}$ & $\begin{array}{l}\text { Both intercept } \\
\text { and trend }\end{array}$ & $\begin{array}{c}q \\
\text { (optimal lags length) }\end{array}$ \\
\hline $\ln \left(M 2_{i} / P_{i}\right)_{t}$ & $\begin{array}{l}3.811 \\
(0.99)\end{array}$ & 2 & $\begin{array}{l}-1.023 \\
(0.153)\end{array}$ & 2 \\
\hline$\Delta \ln \left(M 2_{i} / P_{i}\right)_{t}$ & $\begin{array}{l}-1.846 \\
(0.032)\end{array}$ & 6 & $\begin{array}{l}-8.801 \\
(0.000)\end{array}$ & 0 \\
\hline $\ln \left(Y_{i}\right)_{t}$ & $\begin{array}{c}3.132 \\
(0.999)\end{array}$ & 5 & $\begin{array}{l}1.387 \\
(0.917)\end{array}$ & 6 \\
\hline$\Delta \ln \left(Y_{i}\right)_{t}$ & $\begin{array}{l}-3.428 \\
(0.000)\end{array}$ & 4 & $\begin{array}{l}-4.237 \\
(0.000)\end{array}$ & 4 \\
\hline$\left(R D_{i}-L R_{i}\right)_{t}$ & $\begin{array}{l}-0.768 \\
(0.221)\end{array}$ & 6 & $\begin{array}{l}-0.365 \\
(0.357)\end{array}$ & 1 \\
\hline$\Delta\left(R D_{i}-L R_{i}\right)_{t}$ & $\begin{array}{l}-7.470 \\
(0.000)\end{array}$ & 5 & $\begin{array}{l}-3.578 \\
(0.000)\end{array}$ & 5 \\
\hline $\ln \left(P_{i}\right)_{t}$ & $\begin{array}{l}11.733 \\
(1.000)\end{array}$ & 1 & $\begin{array}{c}6.479 \\
(1.000)\end{array}$ & 1 \\
\hline$\Delta \ln \left(P_{i}\right)_{t}$ & $\begin{array}{l}-3.478 \\
(0.000)\end{array}$ & 2 & $\begin{array}{l}-6.416 \\
(0.000)\end{array}$ & 3 \\
\hline $\ln \left(R E E R_{i}\right)_{t}$ & $\begin{array}{c}4.658 \\
(1.000)\end{array}$ & 3 & $\begin{array}{l}-1.080 \\
(0.140)\end{array}$ & 1 \\
\hline$\Delta \ln \left(R E E R_{i}\right)_{t}$ & $\begin{array}{l}-7.739 \\
(0.000)\end{array}$ & 2 & $\begin{array}{l}-6.417 \\
(0.000)\end{array}$ & 2 \\
\hline$R_{U S, t}$ & $\begin{array}{l}-1.046 \\
(0.147)\end{array}$ & 1 & $\begin{array}{l}-1.647 \\
(0.049)\end{array}$ & 1 \\
\hline$\Delta R_{U S, t}$ & $\begin{array}{l}-2.986 \\
(0.001)\end{array}$ & 0 & $\begin{array}{l}-2.480 \\
(0.006)\end{array}$ & 0 \\
\hline
\end{tabular}

Notes: * The SIC and the Newey-West bandwidth selection method based on the Bartlett kernel are used in the test procedure. Figures in the parentheses represent the corresponding p-values.

Source: Authors' estimation. 
Table 4: Pedroni panel cointegration tests

\begin{tabular}{ccccccc}
\hline \multicolumn{3}{c}{ Panel Cointegration Tests } & \multicolumn{3}{c}{$\begin{array}{c}\text { Group Mean } \\
\text { Cointegration Tests }\end{array}$} \\
\hline v-Stat & rho-Stat & PP-Stat & ADF-Stat & rho-Stat & PP-Stat & ADF-Stat \\
1.84121 & 2.05173 & 3.88595 & 2.15473 & 1.89627 & 3.66798 & 4.12761 \\
$(0.0328)^{*}$ & $(0.0035)^{*}$ & $(0.0025)^{*}$ & $(0.0047)^{*}$ & $(0.0467)^{*}$ & $(0.0039)^{*}$ & $(0.0368)^{*}$ \\
\hline
\end{tabular}

Note: p-values are stated in parentheses; ${ }^{*}$ denotes rejection of null hypothesis at the $5 \%$ critical level (p-value less than 0.05).

Source: Authors' estimation.

Table 5: Redundant fixed effects tests

\begin{tabular}{cccc}
\hline Effects Test & Statistic & d.f. & Prob. \\
\hline Cross-section F & 93.35 & $(5,168)$ & 0.0000 \\
Cross-section Chi-square & 237.94 & 5 & 0.0000 \\
\hline
\end{tabular}


Table 6: Long run determinants of demand for the real balances

\begin{tabular}{|c|c|c|c|c|c|c|}
\hline \multirow[t]{2}{*}{ Independent Variables } & \multicolumn{3}{|c|}{$\begin{array}{l}\text { Fixed effect model with } \\
\text { country specific intercept }\end{array}$} & \multicolumn{3}{|c|}{$\begin{array}{l}\text { Fixed effect model with } \\
\text { country specific intercept } \\
\text { and income elasticity }\end{array}$} \\
\hline & Coefficient & $t$-ratio & $p$-value & Coefficient & $t$-ratio & $p$-value \\
\hline \multicolumn{7}{|l|}{ Country specific intercept } \\
\hline Guinea & 6.317 & 2.55 & 0.01 & 99.711 & 2.06 & 0.04 \\
\hline Ghana & -0.396 & -0.16 & 0.88 & -3.025 & -0.46 & 0.65 \\
\hline Gambia & 1.729 & 0.79 & 0.43 & -22.155 & -3.37 & 0.00 \\
\hline Liberia & -1.715 & -0.78 & 0.43 & 2.134 & 0.63 & 0.53 \\
\hline Serra-Leone & 7.819 & 3.30 & 0.00 & -27.164 & -1.84 & 0.07 \\
\hline Nigeria & 5.712 & 2.06 & 0.04 & 9.319 & 1.35 & 0.18 \\
\hline $\ln \left(Y_{i}\right)_{t}$ & 0.765 & 6.91 & 0.00 & - & - & - \\
\hline \multicolumn{7}{|c|}{ Country specific income elasticity } \\
\hline Guinea & - & - & - & -3.603 & -1.60 & 0.11 \\
\hline Ghana & - & - & - & 0.878 & 2.97 & 0.00 \\
\hline Gambia & - & - & - & 1.956 & 5.889 & 0.00 \\
\hline Liberia & - & - & - & 0.585 & 3.46 & 0.00 \\
\hline Sierra Leone & - & - & - & 2.387 & 3.38 & 0.00 \\
\hline Nigeria & - & - & - & 0.617 & 2.22 & 0.03 \\
\hline$\left(R D_{i}-L R_{i}\right)_{t}$ & -0.009 & -2.46 & 0.02 & -0.008 & 2.07 & 0.04 \\
\hline $\ln \left(P_{i}\right)_{t}$ & 0.134 & 4.51 & 0.00 & 0.091 & 2.43 & 0.01 \\
\hline $\ln \left(R E E R_{i}\right)_{t}$ & -0.001 & -9.85 & 0.00 & -0.004 & -2.22 & 0.03 \\
\hline$R_{U S, t}$ & -0.086 & -4.04 & 0.00 & -0.044 & -2.03 & 0.04 \\
\hline$R^{2}$ & 0.995 & & & 0.993 & & \\
\hline Adjusted $R^{2}$ & 0.995 & & & 0.993 & & \\
\hline $\mathrm{AIC}$ & 3.861 & & & 3.809 & & \\
\hline $\mathrm{SIC}$ & 4.060 & & & 4.100 & & \\
\hline$F$-statistics & 3284 & & 0.00 & 71.17 & & 0.00 \\
\hline $\begin{array}{l}\text { Unit root test for residual } \\
\text { term using IPS test }\end{array}$ & 0.962 & & 0.83 & -2.22 & & 0.01 \\
\hline Jarque-Bera normality test & 3.601 & & 0.34 & 2.780 & & 0.72 \\
\hline $\begin{array}{l}H_{0}^{1}: \delta_{i 0}=\delta_{0} \\
F(5,163)\end{array}$ & 709.3 & & 0.00 & & & \\
\hline$\chi^{2}(5)$ & 3.601 & & 0.34 & 2.780 & & 0.72 \\
\hline $\begin{array}{l}H_{0}^{2}: \delta_{i 1}=\delta_{1} \\
F(5,158)\end{array}$ & & & & 17.31 & & 0.00 \\
\hline$\chi^{2}(5)$ & & & & 86.57 & & 0.00 \\
\hline
\end{tabular}

Note: * the White cross-section standard errors and covariance are used in the estimation of the $t$-ratios. Source: Authors' estimation. 
Table 7: Short run determinants of demand for the real balances

\begin{tabular}{cccc}
\hline Panel Cointegration Tests & \multicolumn{3}{c}{ Group Mean } \\
& \multicolumn{3}{c}{ Cointegration Tests } \\
\hline & Coefficient & t-ratio & $p$-value \\
\hline 1.84121 & 2.05173 & 3.88595 & 2.15473 \\
$(0.0328)^{*}$ & $(0.0035)^{*}$ & $(0.0025)^{*}$ & $(0.0047)^{*}$ \\
\hline
\end{tabular}

Note: $p$-values are stated in parentheses; * denotes rejection of null hypothesis at the $5 \%$ critical level (p-value less than 0.05).

Source: Authors' estimation. 